\title{
DEVELOPMENT AND EVALUATION OF NOODLES PREPARED FROM RICE AND WHEAT FLOUR BLENDS
}

\author{
$[122]$ \\ Maghfara * A. Abd Elfatah, El-kalyoubi M.H., Mostafa M.M. and Ashoush I.S. \\ Food Sci. Dept., Fac. of Agric., Ain Shams Univ., P.O.B 68, Hadayek Shoubra 11241, \\ Cairo, Egypt
}

${ }^{*}$ Corresponding author: Maghfera Monem 500@hotmail.com

Accepted 11 June, 2019

\section{ABSTRACT}

Noodles were prepared by incorporation varying blends $(0,20,40,60$ and $80 \%)$ of rice flour in replacement of wheat flour. Noodle samples were evaluated for their proximate composition, scavenging activity, sensory properties and cooking quality characteristics. The proximate composition of uncooked noodles varied significantly, with increasing rice flour level that replaced wheat flour, gradual decreases in moisture, ash, crude fiber and protein contents in noodle pastes were occurred, their values ranged between $4.02-5.33 \%$; $1.11-5.22 \%, 0.65-0.82 \%$ and $8.51-12.81 \%$, respectively. However, increases in fats, total carbohydrates and energy value were take place ranging between 4.62-8.91\%, 71.11-76.74\% and 377.64 $421.43 \mathrm{kcal} / 100 \mathrm{~g}$, respectively. The antioxidant activity ranged between $22.2 \%$ for wheat based noodle $(100 \%$ wheat flour) to $36.8 \%$ for sample containing $80 \%$ rice flour as scavenging activity for free radicals. The overall acceptability of wheatbased noodles (WF: RF 100:00) were rated maximum for their sensory preferable attributes. While, in others blended flour noodles, the noodles incorporated with up to $40 \%$ rice flour received the same acceptability as wheat-based noodle. The cooking quality characteristics differed significantly in the noodle samples; the cooking time, ranged between 6.5 to 10.3 minutes, it was more in wheatbased noodles than noodles from rice flour. Cooking loss; water absorption percent; cooked weight and swelling index values ranged from 0.1 to $0.6 \%$, 137.1 to $231.6 \%, 23.74$ to $33.24 \mathrm{~g} / \mathrm{g}$ and 3.20 to $5.38 \%$, respectively; which revealed that a significant hindered was occurred in the functional paste properties and cooking quality parameters with increasing the level rice flour in noodles. The study
\end{abstract}

indicated that, noodle blends from mixtures of rice and wheat flour revealed that the best preferable sensory characteristics and cooking quality characteristics were observed at blending ratio $40: 60 \%$ rice flour: wheat flour. These findings enhance the utilization of non- traditional flours like rice flour for production noodles with high nutritional value.

Keywords: Noodles, rice flour, wheat flour, cooking quality, sensory evaluation.

\section{INTRODUCTION}

Noodles are easy of cooking, handling and low cost for consumers; its preparing from ingredients like; wheat flour, salt, and water. Noodles are one of the most consumed foods all over the world. With health concerns, many research concerning about functional foods, like, functional noodles supplemented with spirulina, banana flour and rice flour according to literatures by Prabhasankar et al (2009); Choo and Aziz (2010); Ishfaq et al (2015).

Rice (Oryza Sativa) is the most consumed food in Asian countries; and more healthy than other starchy food; rice flour is a suitable ingredient to present gluten-free foods due to its sensory and reduced allergenic characteristics. Noodles based on rice flour get by wet milling are a favored food in Asia Osella et al (2014).

Rice noodles are a popular noodles with highly recommend for low protein diet for kidney patient, the development of low protein diets has become important; for that reason, rice flour noodles compared to preexisting low-protein products appropriate as a basic raw materials in low protein diet Metzger et al (2018). 
In this study, rice flour was selected for noodles preparation because of its good nutritional properties; for this reason, the aim was to utilization the rice flour to preparing functional noodle and assessment its incorporation in chemical, cooking and sensory of rice based noodles.

\section{MATERIALS AND METHODS}

\section{Materials}

Wheat and rice grains were received from Crop Research Institute, Agricultural Research Center, Ministry of Agriculture, Giza, Egypt. The wheat and rice were milled to flour in a grinder and passed through 80-mesh screen. Wheat and rice flours were kept in sealed containers, at $4^{\circ} \mathrm{C}$ until analysis. Methanol was bought from El-Gomhoreya Co., Cairo, Egypt. Also, 2,2-diphenyl-2-picrylhydrazyl radical (DPPH) were purchased from SigmaAldrich Inc. (St Louis, MO, USA).

\section{Methods}

\section{Preparation of noodles}

The control noodle formula consisted of $100 \mathrm{~g}$ of wheat flour, $40 \mathrm{ml}$ of water and $0.5 \mathrm{~g}$ of salt. Four additional noodle samples were prepared by substituting wheat flour with 20,40, 60 and $80 \%$ rice flour. The different formulations were processed into noodles; the prepared dough was placed to rest in a plastic bag for 30 minutes. The dough was passed through a small noodle hand machine for several times with the rollers gap gradually reduced, the noodle strands were cut with a sharp knife to the appropriate length (12 $\mathrm{cm})$. After cutting, the noodle strands were dried at $50{ }^{\circ} \mathrm{C}$ according to Nermin, (2013).

\section{Proximate analysis of noodles}

The noodles incorporated with rice flour at different ratios were analyzed for their contents of moisture, ash, crude fiber, protein ( $N \times 5.75)$, fat, and carbohydrate calculated by difference according to the methods described in AOAC, (2012). Meanwhile, the energy value was calculated based on their content of crude protein, fat and available carbohydrate using the formula as follows: Energy value $(\mathrm{kcal} / 100 \mathrm{gm})=($ Crude protein $\times 4)+($ carbohydrate $\times 4)+($ Crude fat $\times 9)$ as described in AOAC, (2012).

\section{Determination of scavenging activity for noo- dles}

The ability of the different blending of noodles extracts to scavenging DPPH free radicals was determined by the method described by BrandWilliams et al (1995). The percentage of scavenging effect was calculated from the decreased in absorbance against control according to the following equation:

$$
\begin{gathered}
\text { Scavenging activity } \%=\left[\left(\boldsymbol{A b s}_{\text {control }}-\right.\right. \\
\left.\boldsymbol{A b s}_{\text {sample }}\right) / \boldsymbol{A b S _ { \text { control } }} \times 100
\end{gathered}
$$

\section{Sensory evaluation of noodles}

Ten members semi trained panelists from the staff of Food Science Department Ain Shams University were asked to score all cooked noodle samples for their taste, odor, color, chewiness and overall acceptability; using nine-point hedonic scales, where $9=$ extremely like and $1=$ extremely dislike. Each panelist evaluated five samples (identified by unique three-digit codes) in a balanced sequential order. The optimal ratio of rice flour to wheat flour in the noodles was investigated using sensory qualities in comparison to the control noodles; using a report sheet according to Watts et al (1989).

\section{Cooking quality of noodles}

\section{Cooking Time}

Cooking time was evaluated by observing the time of disappearance of the core of the noodles strand during cooking (every $30 \mathrm{~s}$ ) noodle samples were squeezed between glass slides to transparent Ritthiruangdej et al (2011).

\section{Cooking Loss}

The cooking loss, defined as the amount of solid substances lost into the cooking water, it was determined as depicted in AACC-approved method 66-50.01 AACC, (2000). A 10-g sample of noodles were placed into $500 \mathrm{ml}$ of boiling distilled water and cooked. The cooked noodles were rinsed using $50 \mathrm{ml}$ of distilled water. The cooking water and rinsing water were collected in a beaker and placed into an air oven at $105^{\circ} \mathrm{C}$ until dry. The residue was weighed and reported as a percentage of the starting material. 
flour blends

\section{Swelling index}

The swelling index of cooked noodles was estimated as depicted in AACC-approved method 66-50.01 AACC, (2000) and calculated as follows:

\section{Swelling index $(\%)=$}

(Weight of the cooked noodles) - (Weight of noodles after drying) (Weight of noodles after drying)

\section{Water absorption}

Water absorption was determined according to the AACC-approved method 66-50.01 AACC, (2000). Ten grams of dried noodle samples were pre-weighed and boiled in $300 \mathrm{~mL}$ of water for the cooking time which previously determined. Then, Noodles were removed and weighed, the weight difference before and after cooking was used to calculate the water absorption as follows:

\section{Water absorption (\%)=}

$\frac{\text { Weight of cooked noodles - Weight of raw noodles }}{\text { Weight of raw noodles }} \times 100$

\section{Cooked weight}

Noodles $(10 \mathrm{~g})$ were cooked in $300 \mathrm{ml}$ of distilled water in a beaker to their optimum cooking time, rinsed with distilled water, drained and left to cool for 5 minutes at room temperature. The cooled cooked noodles were then reweighed. The cooked weighed was expressed in grams Kamble et al (2018).

\section{Statistical analysis}

All data were expressed as the mean \pm SE and they were analyzed statistically using the one-way analysis of variance ANOVA followed by Duncan's test. In all cases $p<0.05$ was used as the criterion of statistical significance by SAS program SAS, (1996) according to the procedure reported by Steel et al (1997).

\section{RESULTS AND DISCUSSION}

\section{Proximate composition of noodles}

Data given in Table (1) indicated that the moisture, ash, protein and crude fiber percent increased, when rice flour ratio decreased in the noodles owing to their lower contents in rice flour than wheat flour. On the other hand, the fat and total carbohydrate content increased with increasing rice flour ratio in the noodles. Energy value content of different blends ranged between 377.64 to $421.43 \mathrm{Kcal} / 100 \mathrm{~g}$, the highest values were observed for the rice-based noodles. An elevation in rice flour levels in the blends leads to increasing energy value reaching its maximum value at the ratio of $20 \mathrm{WF}: 80 \mathrm{RF}$. This was expected as rice was composed of mainly carbohydrate-rich materials. These findings are in accordance with those reported by Ishfaq et al (2015).

Table 1. Effect of rice flour incorporation on proximate composition of noodles $(\mathrm{g} / 100 \mathrm{~g})$

\begin{tabular}{|l|c|c|c|c|c|}
\hline \multirow{2}{*}{ Composition } & \multicolumn{5}{c|}{ Noodles } \\
\cline { 2 - 6 } & T1 & T2 & T3 & T4 & T5 \\
\hline Moisture & $5.33^{\mathrm{a}} \pm 0.20$ & $5.39^{\mathrm{a}} \pm 0.11$ & $4.76^{\mathrm{b}} \pm 0.11$ & $4.32^{\mathrm{c}} \pm 0.10$ & $4.02^{\mathrm{c}} \pm 0.04$ \\
Ash & $5.22^{\mathrm{a}} \pm 0.30$ & $5.85^{\mathrm{a}} \pm 0.29$ & $3.53^{\mathrm{b}} \pm 0.21$ & $2.54^{\mathrm{c}} \pm 0.29$ & $1.11^{\mathrm{d}} \pm 0.22$ \\
Fat & $4.62^{\mathrm{d}} \pm 0.19$ & $5.14^{\mathrm{cd}} \pm 0.44$ & $6.11^{\mathrm{bc}} \pm 0.57$ & $7.11^{\mathrm{b}} \pm 0.44$ & $8.91^{\mathrm{a}} \pm 0.36$ \\
Protein & $12.81^{\mathrm{a}} \pm 0.10$ & $11.78^{\mathrm{b}} \pm 0.13$ & $10.71^{\mathrm{c}} \pm 0.21$ & $9.64^{\mathrm{d}} \pm 0.22$ & $8.57^{\mathrm{e}} \pm 0.12$ \\
Crude Fiber & $0.82^{\mathrm{a}} \pm 0.01$ & $0.77^{\mathrm{ab}} \pm 0.03$ & $0.73^{\mathrm{bc}} \pm 0.01$ & $0.69^{\mathrm{cd}} \pm 0.03$ & $0.65^{\mathrm{d}} \pm 0.01$ \\
Total Carbohydrate & $71.18^{\mathrm{c}} \pm 0.16$ & $71.11^{\mathrm{c}} \pm 0.76$ & $74.18^{\mathrm{b}} \pm 0.72$ & $75.68^{\mathrm{ab}} \pm 0.44$ & $76.74^{\mathrm{a}} \pm 0.61$ \\
Energy value (Kcal/100g) & $377.64^{\mathrm{d}} \pm 1.75$ & $377.64^{\mathrm{d}} \pm 0.86$ & $394.21^{\mathrm{c}} \pm 2.33$ & $405.36^{\mathrm{b}} \pm 2.25$ & $421.43^{\mathrm{a}} \pm 1.27$ \\
\hline
\end{tabular}

Data are mean $\pm S E, n=3$, means on the same lines having different superscripts are significantly different at $5 \%$. Where: T1: (WF 100: RF 0); T2: (WF 80: RF 20); T3: (WF 60: RF 40); T4: (WF 40: RF 60); T5: (WF 20: RF 80). 


\section{Scavenging activity of noodles}

The data presented in Table (2) showed that scavenging activity in noodles ranged from 22.2 to $36.8 \%$. The highest percentage was observed for a sample containing $80 \%$ rice flour followed by sample T4, and gradually stepped down with raising wheat flour level till reached the lowest value for wheat-based noodle containing $100 \%$ wheat flour. These results are in harmony with those obtained by Adom and Liu, (2002).

Table 2. Effect of rice flour incorporation on scavenging activity of noodles

\begin{tabular}{|c|c|}
\hline Noodles & Scavenging activity \% \\
\hline T1: (WF 100: RF 0) & $22.18^{\mathrm{d}} \pm 0.14$ \\
T2: (WF 80: RF 20) & $22.88^{\mathrm{d}} \pm 0.22$ \\
T3: (WF 60: RF 40) & $32.48^{\mathrm{c}} \pm 0.10$ \\
T4: (WF 40: RF 60) & $34.19^{\mathrm{b}} \pm 0.10$ \\
T5: (WF 20: RF 80) & $36.79^{\mathrm{a}} \pm 0.49$ \\
\hline
\end{tabular}

Data are mean $\pm S E, n=3$, means on the same column having different superscripts are significantly different at $5 \%$.

\author{
Evaluation of sensory attributes for cooked \\ noodles
}

The cooked noodles were estimated for their sensory attributes included taste, odor, color, chewiness and overall acceptability as shown in Table 3. The data revealed that sensory characteristics scores significantly decreased as the rice flour content increased. The noodles supplemented with up to $40 \%$ rice flour received the same acceptability as the control. Therefor, utilization the rice flour sublementation ratio $40 \%$ could observed good sensory characteristics like wheat-based noodles.

\section{Cooking quality characteristics}

Noodle quality could be estimated from cooking attributes, such as cooking time, cooking loss, water absorption, swelling index and cooked weight. Data in Table 4. containg cooking time, cooking loss and water absorption showed that wheat-based noodles had prolonged cooking time than rice based noodles. Regarding to cooking loss of rice based noodles was higher than wheatbased noodles. On the other hand, the water absorption was found to range between 137.1 to $231.6 \%$, a higher values were due to the incorporation of rice flour. Also, decrease in protein percent were owing to their dilution as a result of rice flour incorporation, it might be responsible for less water retention and increase in water uptake of the noodles.

Table 3. Effect of rice flour incorporation on sensory evaluation of cooked noodles

\begin{tabular}{|c|c|c|c|c|c|}
\hline \multirow{2}{*}{ Noodles } & \multicolumn{5}{|c|}{ Sensory characteristics } \\
\cline { 2 - 6 } & Taste & Odor & Color & Chewiness & Overall acceptability \\
\hline \multirow{2}{*}{ T1 } & $8.1^{\mathrm{a}} \pm 0.31$ & $8.2^{\mathrm{a}} \pm 0.35$ & $8.2^{\mathrm{a}} \pm 0.29$ & $8.3^{\mathrm{a}} \pm 0.33$ & $8.4^{\mathrm{a}} \pm 0.31$ \\
T2 & $8.2^{\mathrm{a}} \pm 0.24$ & $8.6^{\mathrm{a}} \pm 0.22$ & $8.3^{\mathrm{a}} \pm 0.21$ & $8.0^{\mathrm{a}} \pm 0.21$ & $8.1^{\mathrm{a}} \pm 0.17$ \\
T3 & $7.8^{\mathrm{a}} \pm 0.41$ & $7.9^{\mathrm{ab}} \pm 0.27$ & $8.0^{\mathrm{a}} \pm 0.25$ & $7.9^{\mathrm{a}} \pm 0.27$ & $8.3^{\mathrm{a}} \pm 0.33$ \\
T4 & $6.3^{\mathrm{b}} \pm 0.39$ & $6.7^{\mathrm{b}} \pm 0.61$ & $6.8^{\mathrm{b}} \pm 0.61$ & $6.4^{\mathrm{b}} \pm 0.45$ & $6.2^{\mathrm{b}} \pm 0.44$ \\
T5 & $5.2^{\mathrm{b}} \pm 0.51$ & $6.3^{\mathrm{c}} \pm 0.66$ & $6.0^{\mathrm{b}} \pm 0.53$ & $4.9^{\mathrm{c}} \pm 0.45$ & $5.4^{\mathrm{b}} \pm 0.60$ \\
\hline
\end{tabular}

Data are mean $\pm S E, n=3$, means on the same column having different superscripts are significantly different at $5 \%$. Where: T1: (WF 100: RF 0); T2: (WF 80: RF 20); T3: (WF 60: RF 40); T4: (WF 40: RF 60); T5: (WF 20: RF 80). 

flour blends

Table 4. Effect of rice flour incorporation on cooking quality of noodles

\begin{tabular}{|c|c|c|c|}
\hline Noodles & $\begin{array}{c}\text { Cooking time } \\
\text { minutes }\end{array}$ & $\begin{array}{c}\text { Cooking loss } \\
\%\end{array}$ & $\begin{array}{c}\text { Water absorption } \\
\%\end{array}$ \\
\hline T1: (WF 100: RF 0) & $10.3^{\mathrm{a}} \pm 0.23$ & $0.10^{\mathrm{d}} \pm 0.01$ & $137.1^{\mathrm{e}} \pm 0.01$ \\
T2: (WF 80: RF 20) & $9.1^{\mathrm{b}} \pm 0.10$ & $0.10^{\mathrm{d}} \pm 0.01$ & $200.1^{\mathrm{c}} \pm 0.01$ \\
T3: (WF 60: RF 40) & $8.5^{\mathrm{bc}} \pm 0.23$ & $0.17^{\mathrm{c}} \pm 0.01$ & $231.6^{\mathrm{a}} \pm 0.01$ \\
T4: (WF 40: RF 60) & $8.1^{\mathrm{c}} \pm 0.10$ & $0.60^{\mathrm{a}} \pm 0.01$ & $164.9^{\mathrm{d}} \pm 0.01$ \\
T5: (WF 20: RF 80) & $6.5^{\mathrm{d}} \pm 0.23$ & $0.42^{\mathrm{b}} \pm 0.01$ & $205.6^{\mathrm{b}} \pm 0.01$ \\
\hline
\end{tabular}

Data are mean $\pm S E, n=3$, means on the same column having different superscripts are significantly different at $5 \%$.

Regarding to cooked weight, it was variated from 23.74 grams recorded in wheat-based noodles to 33.24 grams recorded in T3 which incorporated by $40 \%$ rice flour as showen in Table 5. The higher cooked weight of rice noodle could be resone to the elevate swelling ability of the noodles as seen in Table 5, which poited out that the maximum swelling index was recorded in noodle incorporated by $80 \%$ rice flour. Therefore, blends with high incorporation by rice flour decresed the properties of dough, nutrient density and cooking attributes of noodles. These findings are supported by the observation of Kaushal and Sharma (2014); Sirichokworrakita et al (2015) and Kamble et al (2018).

Table 5. Effect of rice flour incorporation on swelling index and cooked weight of noodles

\begin{tabular}{|c|c|c|}
\hline Noodles & Swelling index (\%) & Cooked weight (g) \\
\hline T1: (WF 100: RF 0) & $3.95^{\mathrm{d}} \pm 0.10$ & $23.74^{\mathrm{e}} \pm 0.11$ \\
T2: (WF 80: RF 20) & $3.20^{\mathrm{e}} \pm 0.01$ & $30.11^{\mathrm{c}} \pm 0.02$ \\
T3: (WF 60: RF 40) & $4.29^{\mathrm{c}} \pm 0.01$ & $33.24^{\mathrm{a}} \pm 0.02$ \\
T4: (WF 40: RF 60) & $5.10^{\mathrm{b}} \pm 0.03$ & $26.61^{\mathrm{d}} \pm 0.10$ \\
T5: (WF 20: RF 80) & $5.38^{\mathrm{a}} \pm 0.04$ & $30.68^{\mathrm{b}} \pm 0.02$ \\
\hline
\end{tabular}

Data are mean $\pm S E, n=3$, means on the same column having different superscripts are significantly different at $5 \%$.

\section{CONCLUSION}

Based on the aforementioned data, we could conclude that proximate composition including moisture, ash, crude fiber and protein content increased significantly; while; fat, total carbohydrate and energy value contents reduced significantly in the noodle blends having greater percent of wheat flour. The noodles supplemented with rice flour revealed preferable sensory and cooking quality attributes up to $40 \%$ incorporation of rice flour. These findings promote the utilization of rice flour for the production functional noodles with high nutritional properties.

\section{REFERENCES}

AACC, 2000. Approved Methods of Analysis (11 $1^{\text {th }}$ ed.). Title of Pasta and Noodle Cooking Quality-Firmness. AACC International: Method 6650.01, St Paul, MN, U.S.A.

Adom K.K. and Liu R.H. 2002. Antioxidant Activity of Grains. J. Agric. Food Chem., 50, 61826187.

AOAC 2012. Official Methods of Analysis of the Association of Official Analytical Chemistry International, 19 ${ }^{\text {th }}$ Ed., Gaithersburg, Maryland, USA. 
Brand-Williams W., Cuvelier M.E. and Berset C. 1995. Use of a Free Radical Method to Evaluate Antioxidant Activity. Lebensm.-Wiss. u.Technol. LWT, 28, 25-30.

Choo C.L. and Aziz N.A.A. 2010. Effects of banana flour and $\beta$-glucan on the nutritional and sensory evaluation of noodles. Food Chem., 119, 34-40.

Ishfaq A., Ihsan M. Q. and Suraiya J. 2015. Quality evaluation of noodles prepared from blending of broken rice and wheat flour. Starch, 67, 905-912.

Kamble V., Bhuvaneshwari G., Jagadeesh S.L., Vasant M. G. and Deepa T. 2018. Development and Evaluation of Cooking Properties of Instant Noodles Incorporated with Drumstick Leaf Powder and Defatted Soybean Flour. Int. J. Curr. Microbiol. App. Sci., 7(2), 3642-3651.

Kaushal P. and Sharma H.K. 2014. Effect of Incorporating Taro (Colocasia esculenta), Rice (Oryza sativa), and Pigeon Pea (Cajanus cajan) Flour Blends on Noodle Properties. International J. of Food Properties, 17(4), 765781.

Metzger M., Yuan W.L., Haymann J.P., Flamant M., Houillier P., Thervet E., Boffa J.J., Vrtovsnik F., Froissart M. and Bankir L., 2018. Association of a low-protein diet with slower progression of CKD. Kidney Int. Rep. 3, 105-114.

Nermin B. 2013. Some chemical and sensory properties of gluten-free noodle prepared with different legume, pseudocereal and cereal flour blends. J. of Food and Nutrition Research, 52(4), 251-255.
Osella C., de la Torre M. and Sanchez H. 2014. Safe foods for celiac people. Food and Nutrition Sci., 5(9),787-800.

Prabhasankar P., Ganesan P., Bhaskar N., Hirose A., Stephen N., Gowda L.R., Hosokawa M. and Miyashita K. 2009. Edible Japanese seaweed, wakame (Undaria pinnatifida) as an ingredient in pasta: chemical, functional and structural evaluation. Food Chem., 115, 501508.

Ritthiruangdej P., Parnbankled S., Donchedee S. and Wongsagonsup R. 2011. Physical, chemical, textural and sensory properties of dried wheat noodles supplemented with unripe banana flour. Kasetsart J. (Nat. Sci.), 45, 500509.

SAS, 1996. SAS/ Stat Users Guide: Statistics, System for Windows, version 4.10 (release 8.01 TS level 01M0), SAS Inst., Inc. Cary, North Carolina, USA

Sirichokworrakita S., Phetkhuta J. and Khommoon A. 2015. Effect of partial substitution of wheat flour with riceberry flour on quality of noodles. Procedia - Social and Behavioral Sciences, 197, 1006-1012.

Steel R., Torrie J. and Dickey D. 1997. Principles and Procedures of Statistics: A Biometrical Approach. $3^{\text {rd }}$ Ed, McGraw-Hill, New York, USA.

Watts B.M., Ylimaki G.L., Jeffery L.E. and Elias L.G. 1989. Basic sensory methods for food evaluation. Ottawa: The International Development Research Center, 160 p. 
مجلة اتحاد الجامعات العربية للعلوم الزراعية ، جامعة عين شمس ، القاهرة ، مصر

مجلد(27)، عدد(2)، 1489-1482، 2019

Website: http://ajs.journals.ekb.eg

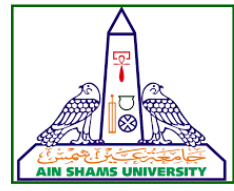

1489

\section{تطوير وتقييم المعكرونة المعدة من خلطات دقيق الأرز والقمح}

[122]

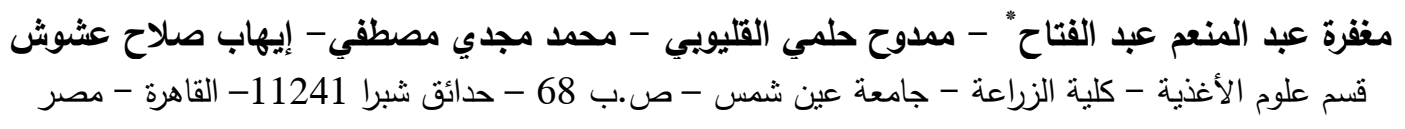

*Corresponding author: Maghfera_Monem_500@hotmail.com

Received 6 May, 2019

Accepted 11 June, 2019

المعكرونة المدمج بها دقيق الأرز بنسبة تصل إلى الى

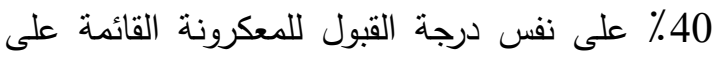

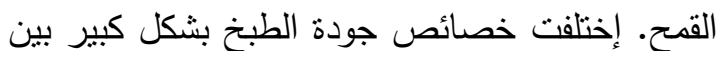

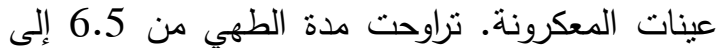

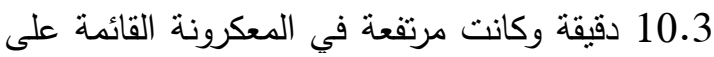

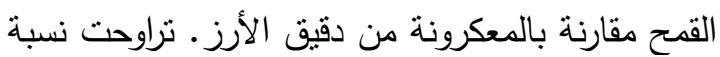

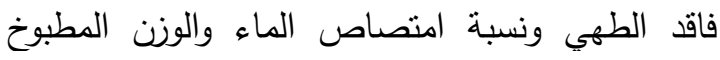

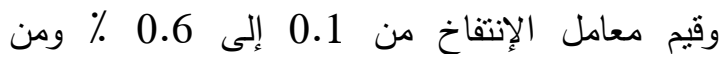

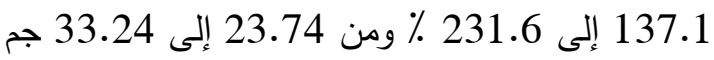

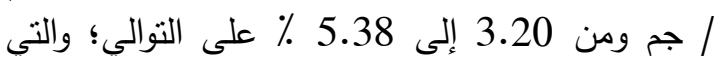
كثفت عن إنخفاض معنوى فى الخصائص الوظيفية

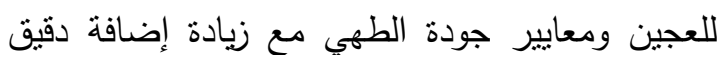

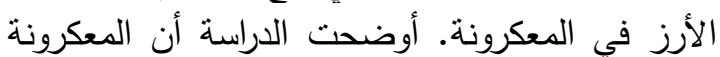

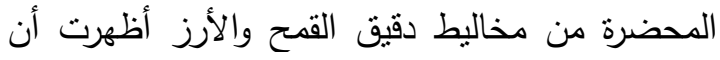

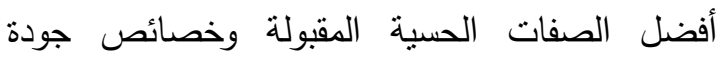
الطهي كانت بنسبة خلط 40٪ من دقيق الأرز مع 60

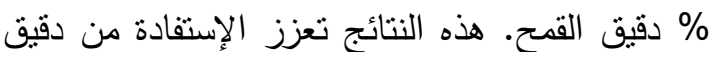

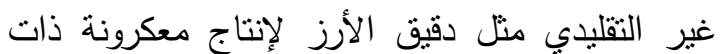
قيمة غذائية عالية.

الكلمات الدالة: المعكرونة، دقيق الأرز، دقيق القمح،

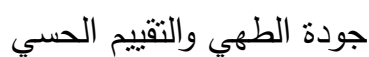

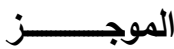

تم إنتاج المعكرونة عن طريق دمج نسب متفاوتة

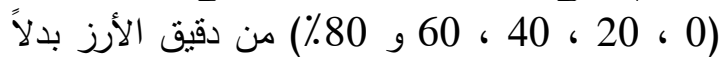

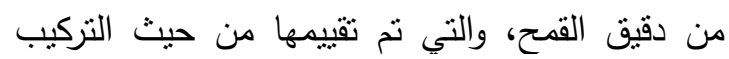
الكيميائي، نشاط الكسح، الخواص الحسية وخئ وخصائص

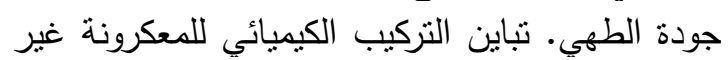

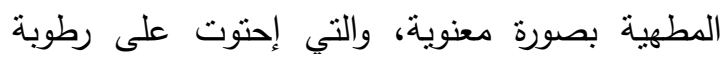

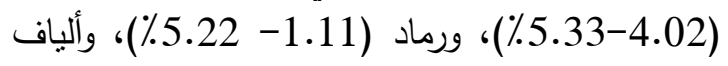

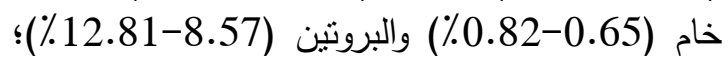
التى زادت عند خفض نسبة دقيق الأرز في المبرون المعكرونة؛

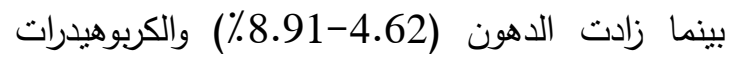

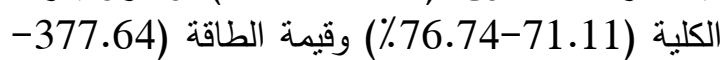

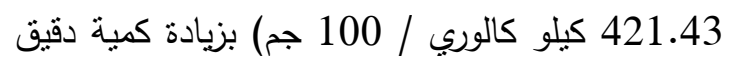
الأرز في المعكرونة. تراوحت فعالية مضادات الأكسدة بين 36.8 \% اللعينة التي تحتوي على دقئ دقيق الأرز

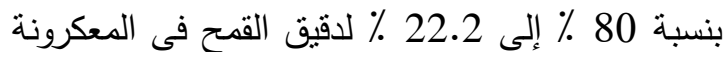
القائمة على القمح بنسبة 100 \% كنشاط كاسح للجذور

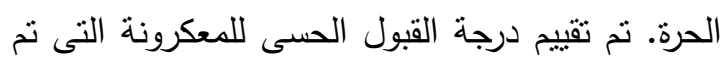
إعدادها، وقد أظهرت المعكرونة القائمة على القئ القيح (WF: RF 100:00)

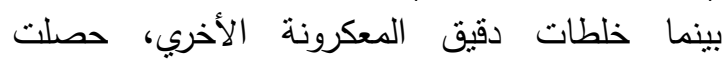

